\title{
PTV法による複断面開水路流れの 時空間相関解析
}

\author{
袷津家久 ${ }^{1} \cdot$ 阿部崇 ${ }^{2} \cdot$ 志村拓也 $^{3} \cdot$ 中山忠暢 $^{4}$ \\ ${ }^{1}$ 正会貝 工博 京都大学助教授 桭境地球工学教室（广606 京都市左京区吉田本町） \\ 2正会貝 工修 (株)竹中土木 \\ 3正会員 工修 (株)筁池組 \\ 4学生会貝 京都大学大学院 環境地球工学専攻
}

\begin{abstract}
複断面開水路流れにおいて, 流速の大きい低水路内の流体と流速の小さい高水教上の流体との境界部にせ ん断層が形成され，斜昇流に代表される組樴構造が間欠的に発生する. 本研究はこの組織構造の特性を調べ るために, 近年の画像解析手法の急激な進展の中で生まれたPTV法を用いて2次元内の多点同時べクトルを 求め，それを基に時空間相関解析や条件付きサンプリング手法によって複断面開水路内の時空間的な現象の 解明を行ったものである．その際に，PTV法の精度を検証するために，同一水理条件の下での高精度なフォ イバーレーザ流速計(FLDA)による計測との比較を行った。
\end{abstract}

Key Words : compound open-channel flow, secondary current, coherent vortex, space-time correlation, PTV

\section{1. 緒論}

複断面開水路は，低水路と高水敷の境界によって 水理量が不連続的に変化する．低水路と高水敷との 流速差はせん断層を形成し, 運動量・物質の輸送原 因・大規模平面渦の発生原因となる，この大規模渦 は, 高水敷先端より低水路側水面に向かって発生す る間欠性と三次元性を有する斜昇流を生み, 発生・ 発達・消滅を繰り返す組織渦によって低運動量の流 体塊が低水路側の水面付近に輸送される.

また, 芦田ら(1988)1)は,この組織渦によって浮遊 砂が高水敷に運び上げられ，掃流力が低下して多く が堆積するといった高水敷管理上好ましくない現象 を取り扱っている.

複断面開水路に形成される組織構造は, 鉛直軸を 有する大規模平面渦と高水敷端部から間欠的に発生 する斜昇流の2種類に大まかに分類でき, 福岡・藤田 (1989)2)は両者の発生条件として水路幅・水深等を基 準として選んでいる. 今本ら $(1992)^{3)}$ は両者の混合機 構を, カメロン効果を利用した瞬間速度の平面分布 で確認し, かつ統計的特性を検討して, 境界部の混 合域の特性を論じている. 平面渦については, 低水
路と高水敷の運動量交換に注目してせん断応力を評 価し抵抗則を導いている玉井・河原 $(1981)^{4)}$ の研究 や，水平渦の発生を変曲点不安定性と非対称渦列の 安定性により説明し，さらに2台の点計測を同時に行 い条件付きアンサンブル平均法を用いて水平渦の3次 元平均像を捉えた池田ら(1995) 流については, Tominaga and Nezu(1991)のはファイ バーレーザ流速計(FLDA)を用いて複断面開水路流れ の精密な3次元乱流計測を行っている.また乱流モデ ルを用いた数值計算法の発達により Naotら(1993a,b) 7),8)は境界部の乱れの非等方性をうまくモデル化する ことによって単断面のモデルを複断面に拡張し, 三 次元代数応力モデルを提案した.

以上の論文においては, ホットフィルム流速計や レーザ流速計による点計測法が一般的であり, 特に 後者の流速計は高精度に流速成分を計測することが できる。しかし，組織構造の瞬間的な特性を検証す るには, 瞬間的な広域流れ場の情報が得られる可視 化手法も重要になってくる. 可視化手法としては, 従来より, 水素気泡法 - 染料注入法 - 微細粒子法等 が用いられてきており, 諸現象の物理的理解を容易 にするという特徴を持っている. それらを写真撮影 

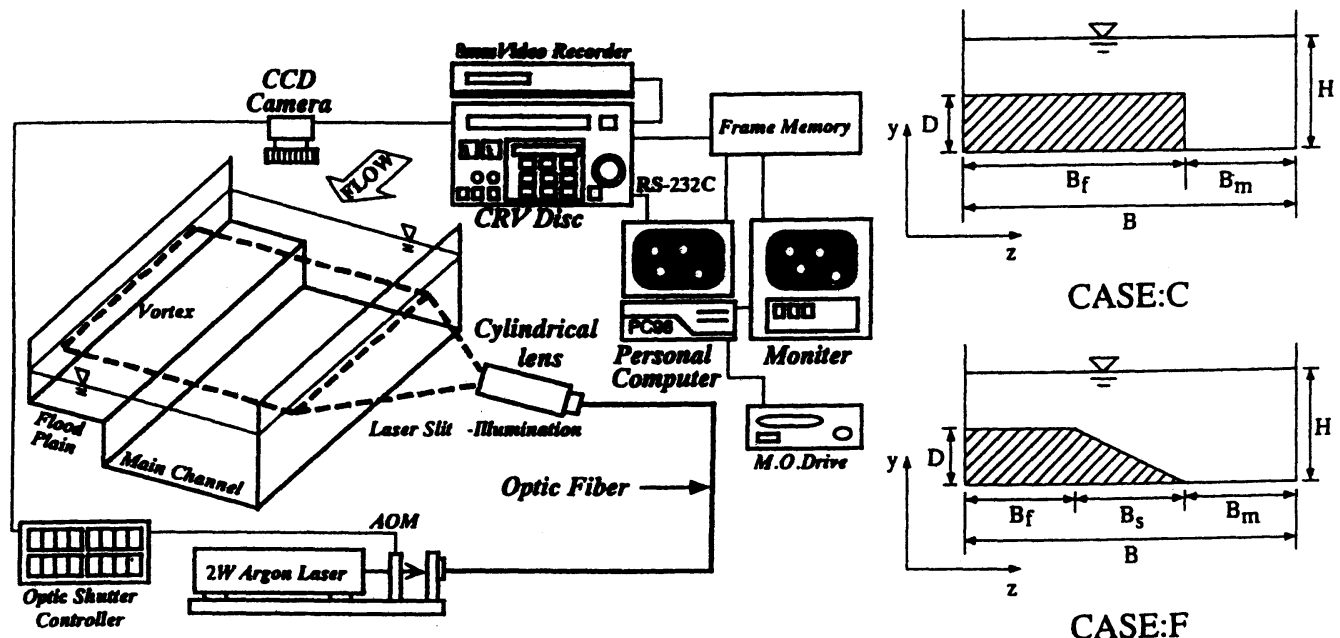

CASE:F

図-1 可視化および画像解析装置

表-1 水理条件

\begin{tabular}{|c|c|c|c|c|c|c|c|c|c|c|}
\hline CASE & 16 & $\underset{(\mathrm{cm})}{H}$ & $B_{m} / B$ & $D: B_{S}$ & $H / D$ & $\underset{(\ell / s)}{Q}$ & $\underset{(\mathrm{cm} / \mathrm{s})}{\bar{U}}$ & $U_{\max }$ & $\begin{array}{c}R_{\theta} \\
\left(\times 10^{3}\right)\end{array}$ & $F r$ \\
\hline $\mathbf{C}$ & $1 / 10000$ & 10.0 & 0.333 & $1: 0$ & 2.0 & 1.29 & 6.4 & 16.0 & 2.7 & 0.07 \\
\hline $\bar{F}$ & $1 / 10000$ & 10.0 & 0.333 & $1: 2$ & 2.0 & 3.00 & 13.2 & 16.7 & 6.6 & 0.13 \\
\hline
\end{tabular}

やビデオ撮影とともに用いることによって再生・保 存が容易になり, 定量的評価への開発も行われてい る. Utami and Ueno(1987)9は連続断層面撮影法を用 いて大規模乱流構造の可視化を行い, その結果を時 空間相関解析に適用した. 木下ら $(1991)^{100}$ は, 洪水時 の実河川に対して航空写真を用いて画像解析を行 い, 大規模渦の存在を定量的に示している.

近年, シート状のレーザ光線(LLS)とCCDカメラを 用いて流れに追随する微細粒子を可視化し, 広領域 の流速場を瞬時に画像解析する技術が開発されてき た. 本研究で用いるPTV(Particle-TrackingVelocimetry)法11),12)がそれに該当し, 空間内の瞬時の 多点速度情報を得ることができる，このPTV法を用 いることによって, 従来計測が困難であった複断面 開水路流れにおける低水路と高水敷間の時空間的な 相互作用を計測できるようになり, 組織渦のメカニ ズムを検討する第一歩とすることが本研究の目的で ある。

\section{2. 実験方法および解析方法}

\section{（1）実験条件および可視化手法}

本実験で使用した水路は, 全長 $8 \mathrm{~m}$, 幅 $30 \mathrm{~cm}$, 高さ $25 \mathrm{~cm}$ のアクリル製可変勾配型循環式水路である. 図1に示すように, 水路長 $8 \mathrm{~m}$ のうち上流部と下流部そ

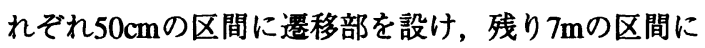

非対称複断面水路形状のアクリル製BOXを右岸側に 設けた. 計測地点は流れが十分に発達している水路 上流端から $5 \mathrm{~m}$ とした，表-1に示すように，実験は等 流状態が実現された, 法面勾配が90度のCASE:Cと 26.7度のCASE:Fの2通りについて行われた。

可視化手法において重要な点は明暸な画像を撮影 することであり, 画像の鮮明度は以降の画像解析の 精度と労力を大きく左右するため, トレーサ粒子の 選定は可視化を行うにあたって重要である。 まず第 一に, トレーサは十分微細で中立浮遊であり, 周囲 の流体に完全に追随してトレーサ粒子速度でその点 の流体の流速を代表できることが必要である. 第二 に, 画像内のトレーサ粒子濃度が適切である必要が ある. 第三に, 撮影画像からトレーサ粒子だげを分 離・認識できる必要があり, トレーサの輝度が画像 背景の輝度よりも大きい必要がある。

以上のことを考虑して本研究では, トレーサ粒子 として直径 $100 \mu \mathrm{m}$, 比重1.02のナイロン12粒子を用 い，水中に拡散しやすいようにエタノールに浸して 循環式水路に一様に混入した。このような微細なト レーサ粒子を鮮明に撮影するためには高強度のレー ザ光線が不可欠である．図-1に示すように2Wのアル コンイオンレーザを光ファイバーケーブルに通し て, シリンドリカルレンズによって厚さ $2 \mathrm{~mm}$ のレー ザライトシート(LLS)として水路側面に水平に照射し た. 従って, レーザ流速計も含めた従来の計測機器 


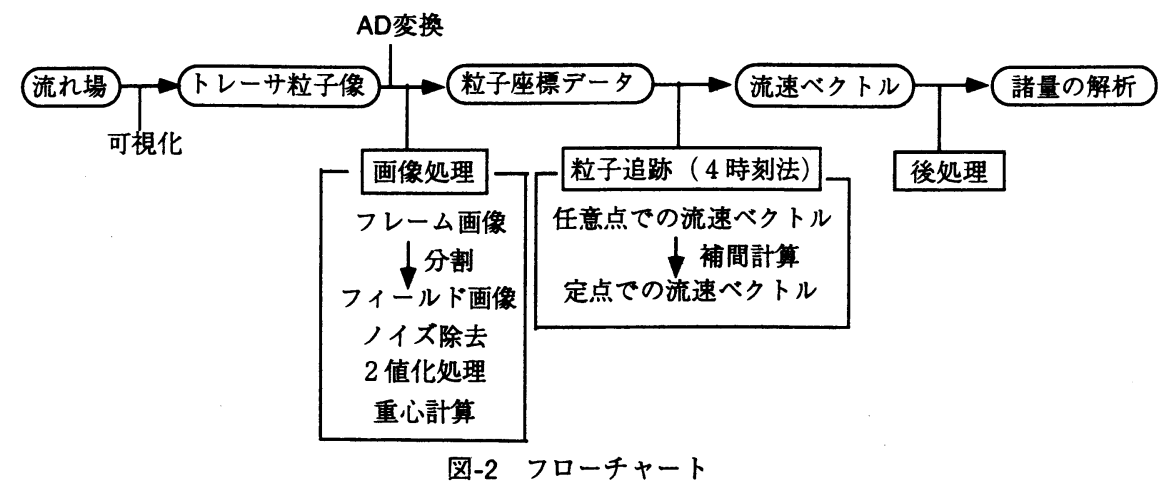

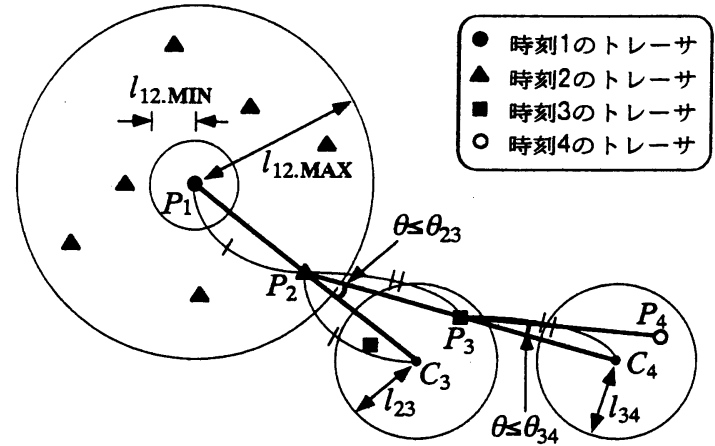

図-3 粒子追跡アルゴリズム

では計測できない，高水敷水深の浅い複断面開水路 流れのような, 浅水流の計測には本研究で用いる PTV法は非常に有効である。撮影は水路上方に設置 されたCCDカメラを通して行われ，光ディスクに画 像を記録した，その際に，479×479ピクセルの画像 解析区間が $20 \times 20 \mathrm{~cm}$ に対応するようにし，ピクセル と実長との関係が倍率で一意的に定まるようにし た.

\section{（2）画像解析法}

図-2は画像解析のフローチャートである. 光ディ スクの画像1コマは479×479ピクセルの格子目盛から なり，1/30secの間の画像情報が記録されていて, フ レーム画像と呼ばれる。本研究では，2時刻のトレー サ粒子が混在するこの再生画像を $1 / 60 \mathrm{sec}$ の画像情報 を持つ2枚のフィールド画像に分離して, 線形補間を 用いて瞬時のトレーサの位置を検出した.

以上で決定された粒子座標を用いて流速ベクトル が決定される，その際に，真にトレーサと思われる もののみを抽出するために，ノイズ除去・2値化・画 像改善などが行われた，図-3は粒子追跡のアルコリ ズムであり，流速べクトルを決定するために，連続 した4コマのフィールド画像のトレーサを追跡する. その際に，以下のように6つのパラメータが設定され る.まず最初に1時刻目のフィールド画像において任
意の粒子 $P_{1}$ が選ばれる. 次に 2 時刻目のフィールド画 像において, 1 時刻目の $P_{1}$ からの距離が $l_{12 \text { MIN }}$ と $l_{12 \text { MAx }}$ の間にあるような特定の粒子 $P_{2}$ が選ばれる。.このP は $P_{1}$ と同一の粒子の可能性のある粒子である. 次に3 時刻目のフィールド画像において, 線分 $P_{1} P_{2}$ の延長 線上で1時刻目の $P_{1}$ から 2 時刻目の $P_{2}$ までに移流され た距離と等しい距離の点が予想位置 $C_{3}$ と考えられ る.これより, この $C_{3}$ を中心とした半径 $l_{23}$ の円内に あり, 線分 $P_{2} C_{3}$ とのなす角が $\theta_{23}$ 以内の粒子 $P_{3}$ が採用 される. 次に4時刻目のフィールド画像において, 同 様に, 線分 $P_{2} P_{3}$ の延長線上で同じように移流された 予想位置 $C_{4}$ を考える.これより，このC た半径 $l_{34}$ の円内にあり, 線分 $P_{3} C_{4}$ とのなす角が $\theta_{34}$ 以 内の粒子 $P_{4}$ が探用される. 以上より, 時刻1-2-3-4と 進むにつれて, 最初の時刻における粒子と同一の可 能性の粒子が制限されていき，4時刻を通しての最適 粒子が選択される ${ }^{11)}$. 6つのパラメータは前もって誤 追跡が最小になるように試行錯誤的に決定してお く. 粒子追跡にはカルマンフィルター推定理論がア ルゴリズムとして使われており, 最適粒子をトレー スできる工夫がなされている，以上による本解析で の誤追跡の発生確率は $1 / 10^{4}$ 程度であり, 誤追跡が最 小限しか発生しないようにパラメータの設定を最大 限繷しくした。 これより, 流速べクトルは, 個々の 粒子の4時刻間における $3 / 60 \mathrm{sec}$ の間の始点と終点の座 標から計算される. 本研究においてはLLSの厚さは 2mm程度であるが, Tominaga and Nezu(1991) 計測によって求めているように, 低水路水深が高水 敷高さの2倍の時, 2次流のオーダーは最大主流速の5 \%程度であることを考虑すると, 本研究のように最 大主流速が高々 $20 \mathrm{~cm} / \mathrm{s}$ の場合には3/60secの間に粒子 がLLS面内にとどまるものと考えられる，以上によっ て求めた流速べクトルは任意点におけるものであ ク，以降の解析のために格子点での流速べクトルに 補間を行った。 補間方法として, 補間する格子点と の距離の逆関数となる重み付け平均を用いた. 


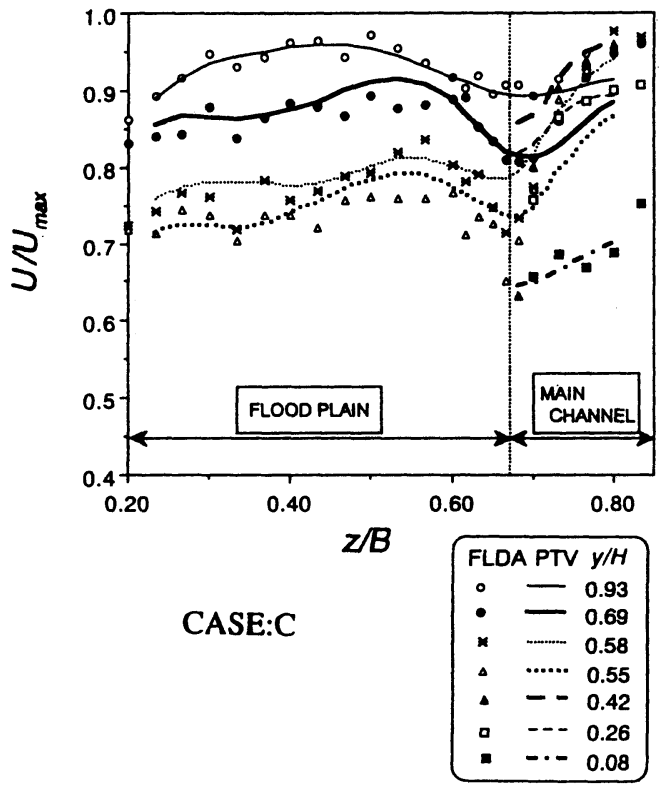

(a)平均主流速 $U$ の分布

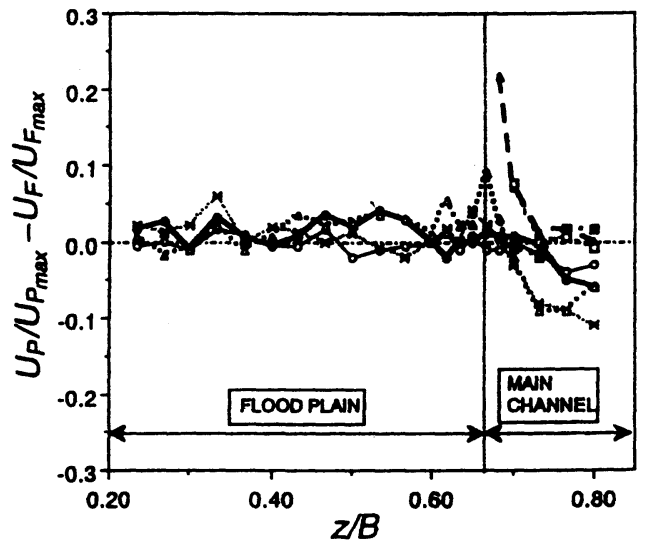

CASE:C

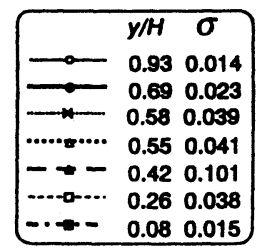

(b)誤差分布

図-4 PTVおよびFLDA計測の比較

\section{3. 実験結果とその考察}

\section{（1）PTV法の精度の検証}

PTV法は同一平面内の多点での流速変動が得られ るという長所を持つ反面, 厳密に言うとトレーサ粒 子の流れへの追随性・画像解析や補間による誤差を 持つ.その結果, 生データにはこれらの原因による ノイズ成分が含まれているため，まず，この高周波 のノイズ成分をフーリエ級数を用いた数値フィル ターによって取り除いた. フーリエ項の次数は可視 化による組織渦の周期等を考虑に入れて161次とし た.

予備実験として, 前章で述べたアルコリズムを用 いたPTV法で, 空間の任意点での流速変動を求め, そのスペクトル分布型を計算した ${ }^{12}$. その結果, 最 も普遍的な特性であるKolmogoroffの-5/3乗則が良好 に成立することが判明した，換言すれば，本PTV法 は複断面流れのような複雑な幾何形状を持つ流れに 対して, 点計測においても乱流計測がかなりの精度 で行えることがわかった。

本研究では組織渦構造を研究するにあたってまず PTV計測の精度や有効性を調べる必要があるため, 同一水理条件の下でのファイバーレーザ流速計 (FLDA)による計測結果との比較を行った，図-4(a)は CASE:Cに対する，FLDAおよびPTV計測による平均 主流速Uについての横断分布の比較であり, 図-4(b) はFLDA計測結果 $\left(U_{F}\right)$ を真值とみなしたときのPTV法
の計測(UP)誤差である，その際に，それぞれほほ同 一点での最大流速で無次元化してある. また, 両者 の計測值 $\left(X_{P T V}, X\right.$ FLDA $)$ に関する標準偏差 $\sigma$ は次式で 表される.

$$
\sigma=\sqrt{\frac{1}{M} \sum_{i=1}^{M}\left(\frac{X_{P T V_{i}}}{X_{P T V_{\max }}}-\frac{X_{F L D A_{i}}}{X_{F L D A_{\max }}}\right)^{2}}
$$

ただし，Mは測点数である。これより境界部や画像 解析範囲の端部で誤差が大きくなる特性がわかる. 境界部では, 高水敷先端部での流速勾配が著しく大 きく乱れも大きいために粒子追随性が悪くなり，ま た, 複断面流れに特徴的な流れの3次元性が顕現した 結果と考えられる。画像解析範囲の端部では解析区 間の両端において追跡べクトルが少なくなり，補間 精度が落ちるためである。しかし，全体的に誤差は5 \%程度でありPTVによる計測は比較的良い精度を持 つことがわかる ${ }^{10)}$. また平均主流速の標準偏差 $\sigma$ の 鉛直方向分布は高水敷高さ付近で最大になってお り, 垂直面内の2次流の影響が現れていると考えられ る.

\section{（2）無条件時空间相関解析}

PTV法では平面内の多点同時計測が可能であり, 従来のようにTaylorの凍結乱流の仮説を用いて時間 相関から空間相関を求める必要がない点が最大の利 点である.このように, PTV法を用いることによっ て平面内ではあるが時空間相関特性を求めることが 


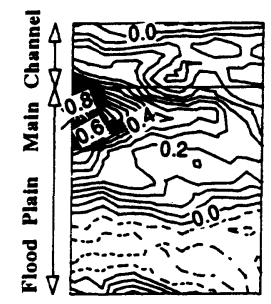

$\tau=0 / 30(s)$

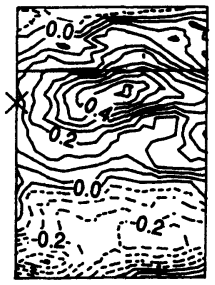

$15 / 30$ (s)

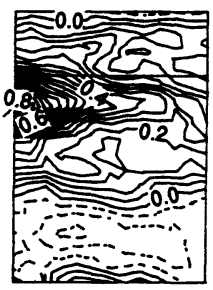

$3 / 30(s)$

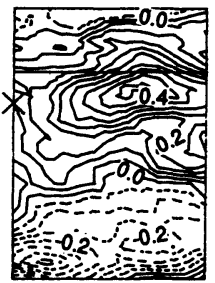

$18 / 30$ (s)

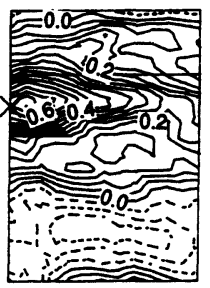

$6 / 30(s)$

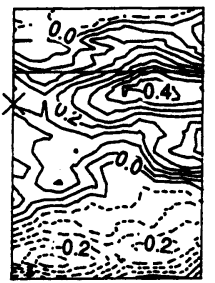

$21 / 30$ (s)

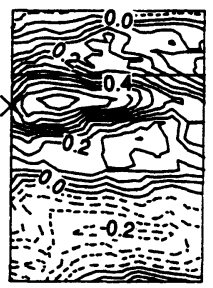

$9 / 30(s)$

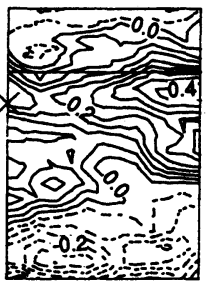

$24 / 30$ (s)

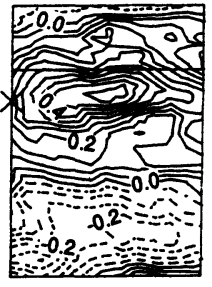

$12 / 30$ (s)

(a) Cuu (CASE:C, $y / H=0.58$ )

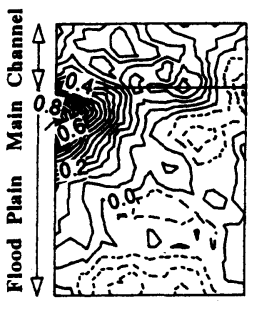

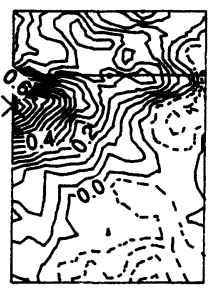

$3 / 30(s)$

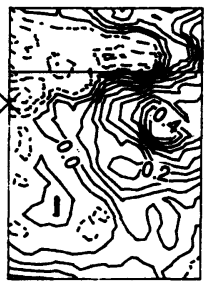

$18 / 30(s)$

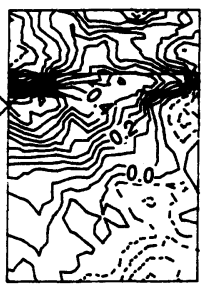

$6 / 30(s)$

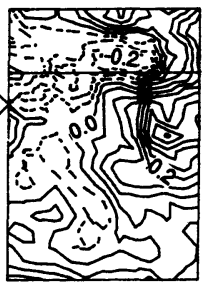

$21 / 30(s)$

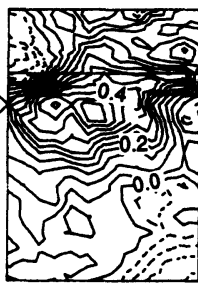

$9 / 30(s)$

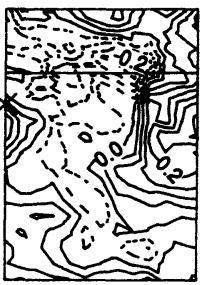

$24 / 30$ (s)

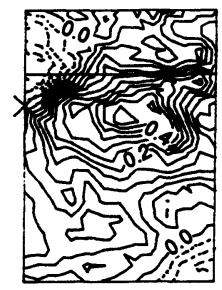

$12 / 30$ (s)

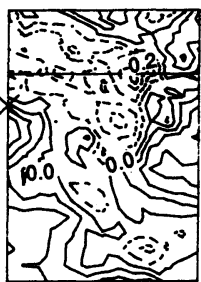

$27 / 30$ (s)

(b) Cww (CASE:C, $y / H=0.85$ )

図-5 時空間相関係数

可能であり，複断面開水路流れにおいて高水敷と低 水路間の相互作用で発生する大規模な組織渦を解析 できる点が特長である.

固定点 $P$ と任意点 $Q$ における流速変動成分 $u_{i}, u_{j} に$ 関する時空間相関係数 $C u_{i} u_{j}$ は, 遅れ距離を $\Delta x, \Delta z$, 遅れ時間を $\tau$, 乱れ強度を $u_{i}{ }^{\prime}, u_{j}^{\prime}$ として次式で定義さ れる.

$$
\begin{aligned}
& C_{u_{i} u_{j}}\left(x_{0}, z_{0}, t ; \Delta x, \Delta z, \tau\right) \\
& =\frac{u_{i}\left(x_{0}, z_{0}, t\right) u_{j}\left(x_{0}+\Delta x, z_{0}+\Delta z, t+\tau\right)}{u_{i}^{\prime}\left(x_{0}, z_{0}\right) u_{j}^{\prime}\left(x_{0}+\Delta x, z_{0}+\Delta z\right)}
\end{aligned}
$$

図-5は固定点 $\times$ に対する主流方向及び横断方向そ れぞれの乱れ成分の時空間相関保数 $C_{u u}, C_{w n}$ の分 布であり, 高水敷高さ付近 $(y / H=0.58)$ と水面付近 $(y / H$ $=0.85)$ に対するものである．点線は負の値を表す。 


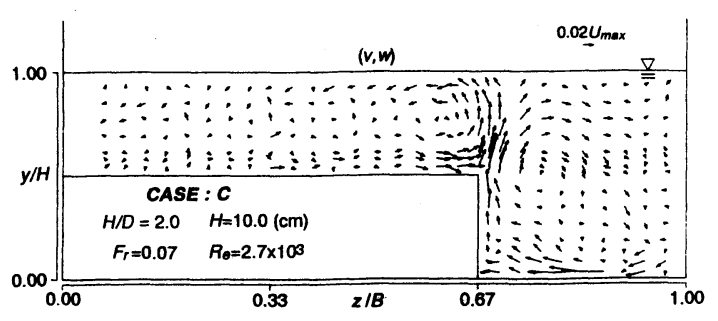

(a)CASE:C

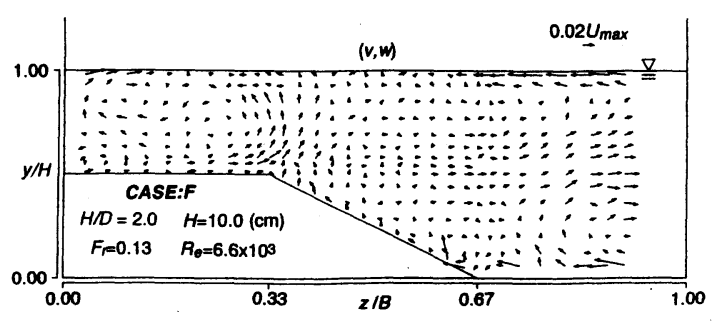

(b)CASE:F

図-6 二次流ベクトル図 (FLDA)

表-2 移流速度と平均流速

\begin{tabular}{|c|c|c|c|}
\hline \multicolumn{2}{|c|}{ fixed point } & $\overline{U_{c}} / \bar{U}$ & $\bar{W}_{c} / \bar{W}$ \\
\cline { 1 - 2 }$y / H$ & $z / B$ & & \\
\hline \hline 0.85 & 0.60 & 0.967 & 0.000 \\
\hline 0.85 & 0.73 & 0.988 & 0.604 \\
\hline 0.58 & 0.73 & 0.991 & 3.264 \\
\hline
\end{tabular}

解析範囲は，流下方向に $12 \mathrm{~cm}$ ，横断方向に $17 \mathrm{~cm}$ あ る.一般に時間とともに高相関領域のピークが低く なるとともに主に主流方向に伸びていく特性が見ら れ，水面に近いほど高相関領域が保持されやすかっ た. 複断面に特徴的な傾向として, 単断面の場合と の比較より次のようなことがわかった。まず第一 に，図-5の(b)のC $w$ hに影著に見られるように，固定 点から境界部に向かって相関の減少する勾配が非常 に大きいことである、このことと関連するが, 高水 敷側の境界部から離れたところに固定点がある場合 には相関領域があまり変化せずに移流していくのに 対して, 低水路側の境界部付近に固定点がある場合 には低相関領域が拡大して移流していく傾向が見ら れた．第二に，高水敷高さ付近ては相関が低水路側 へ移流される場合が多かったのに対して，水面付近 では高水敷側へ移流される場合が多かったことであ る.このことは今本・石垣(1990) ${ }^{13)}$ の研究にも見られ るように流体の移動・混合現象と関わっている。図6は同一水理条件の下でFLDAによって計測された二

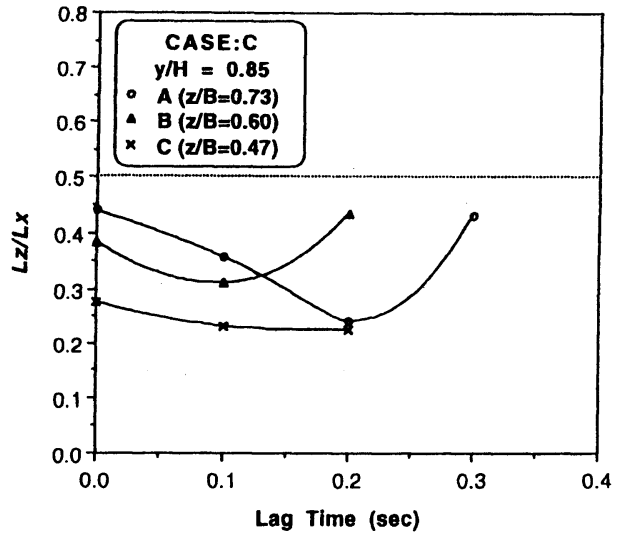

(a) $y / H=0.85$

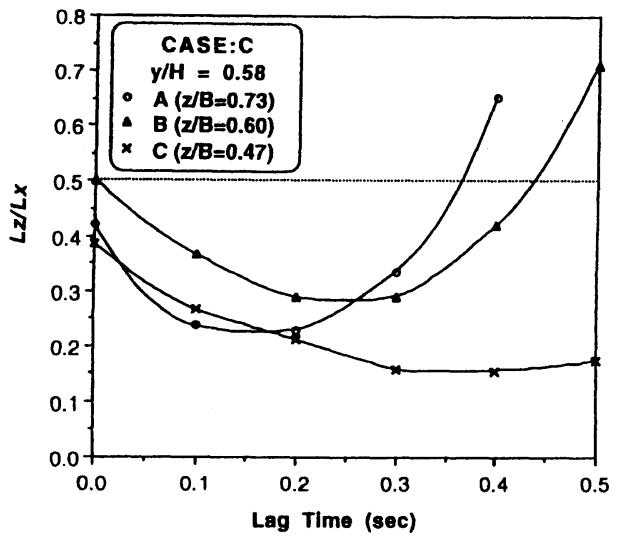

(b) $y / H=0.58$

図-7 偏平率の時間変化

次流ベクトルである。図-5と図-6の比較より, 上記 の特性は斜昇流によって高水敷側に形成される二次 流セルの影響であると考えられる．法面のある CASE:Fの場合でもこの特性が見られたが, CASE:C ほど顕著には見られなかった。

表-2はCASE:Cに対する渦の移流速度 $\overline{U_{c}}, \overline{W_{c}}$ と断面 平均流速 $\bar{U}, \bar{W}$ との関係を示しており, 主流方向に対 しては移流速度は平均流速の約9割となり従来の結果 とほほ一致するが, 横断方向に対してはスケールが 小さく補間が適当でなかったため値にばらつきが見 られる。

流下方向・横断方向の平均渦径はそれぞれ次式で 与えられる。

$$
\begin{aligned}
& L_{x}=\int_{0}^{\infty} C_{u u}(\Delta x, \Delta z=0, \tau) d(\Delta x) \\
& L_{z}=\int_{0}^{\infty} C_{u u}(\Delta x=0, \Delta z, \tau) d(\Delta z)
\end{aligned}
$$

図-7は遅れ時間に対する横断方向・流下方向の平均 渦径の代表値の比(偏平率 $\Gamma=L_{2} / L_{x}$ )の分布である. 


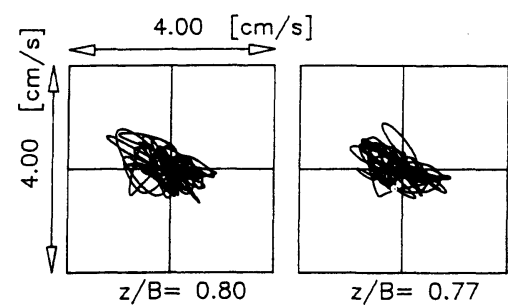

$z / B=0.77$

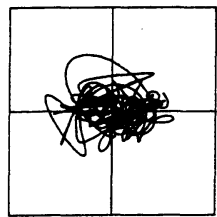

$z / B=0.63$

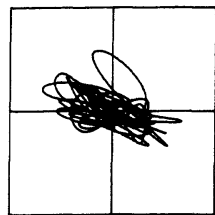

$z / B=0.73$

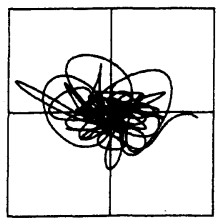

$z / B=0.53$

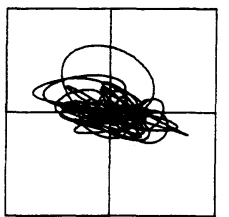

$z / B=0.70$

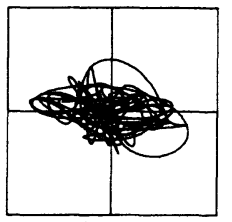

$z / B=0.47$
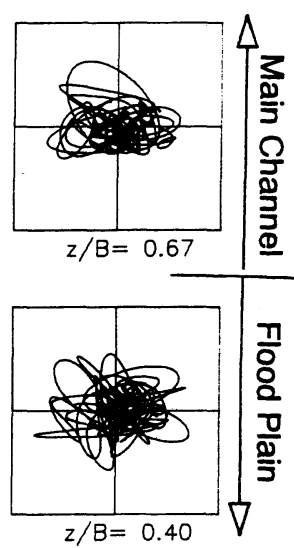

CASE:C y $/ \mathrm{H}=0.58$

図-8 乱れ成分の変動軌跡
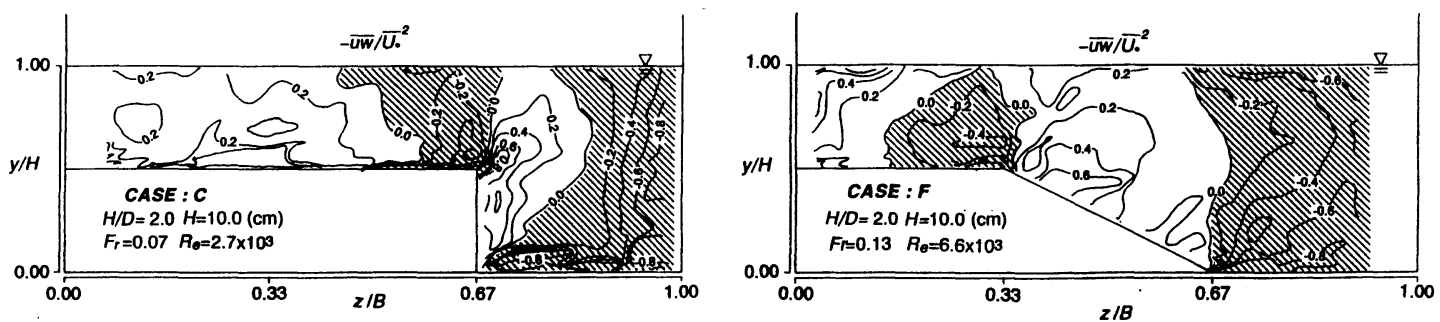

図-9 レイノルズ応カのコンター (FLDA)

ここで渦径の代表値として, 式(3),(4)における積分範 囲を無限大にとるかわりに, 相関係数が最初に極大 值の50\%をとるまでに囲まれる面積を探用した，高 水敷高さ付近 $(y / H=0.58)$ においては, 高水敷上の境 界部から離れたところ(基点C)では時間とともに偏平 率が単調減少するのに対して, 低水路の境界部近傍 (基点 $\mathrm{A})$ や高水敷上の境界部近傍(基点 $\mathrm{B}$ )では偏平率 がいったん減少するがある時刻を境に増加してい き，異なる特性が見られた。これは，境界部に近い ほどある時間を境にして, 流下方向に比べて横断方 向の混合作用の方が大きくなることを示している. 水面付近 $(y / H=0.85)$ に扔いては高水敷高さ付近 $(y / H$ $=0.58$ )ほど顕著ではないが, やはり同様の.特性が見 られた。

\section{（3）条件付き時空间相関解析}

前節の無条件時空間相関解析では時空間的に流速 の時系列全てを平均化してしまい，間欠性のある組 織渦の構造・位相パターンや輸送現象は一律的に平 滑化され打ち消されてしまう恐れがある．そこで特 有のパターンに適合したり判定条件を満足した特性 量のみを抽出し, 時空間相関における時空間的な乱
流変動量を抽出後に集合平均することを試みた．本 研究では, 壁面近傍のバースト現象に条件付きサン プリング手法の1つである四象限区分法を用いたNezu \& Nakagawa(1993) $)^{14)}$ と同様の手法を用いて解析を 行った.

図-8はフーリエ級数分離を用いて高周波のノイズ 成分を取り除いた瞬間流速 $\widetilde{u}, \widetilde{w}$ の乱れ成分 $u, w$ の時 系列である．それぞれの図の横軸は主流方向の乱れ 成分 $u$, 縦軸は横断方向の乱れ成分 $w$ である. 高水 敷側のJunction近傍では $u-w$ 平面内の4つの象限にほ ほ等しく分布するのに対して, 低水路側では第二象 限 $(u<0, w>0)$ と第四象限 $(u>0, w<0)$ に偏る傾 向が見られる．図-9はFLDAによって計測されたレイ ノルズ応力のコンターであり, Junctionから低水路側 にかけて正のレイノルズ応力の領域が拡がってい る.これより，PTV計測による図-8の結果はFLDA計 測による図-9と良く対応している，図-10は図-8を模 式的に描いたものであり，しきい値 $H^{\prime}$ を図のように 設定し, 以降の条件付き時空間相関解析を行う.し きい值 $H^{\prime}$ が大きくなるほど選ばれる組織渦の条件が 蕨しくなる。 


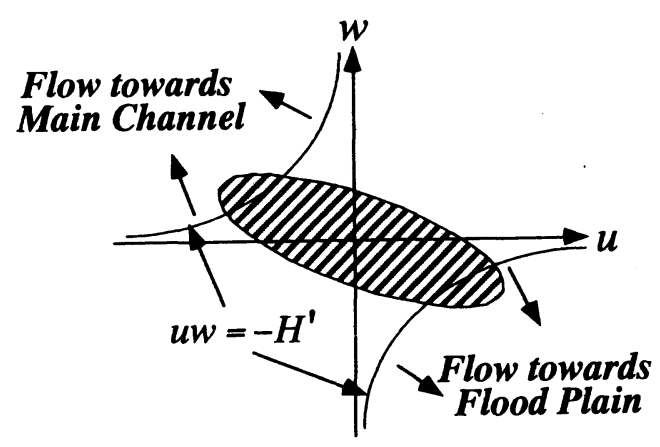

図-10 しきい值 $H^{\prime}$ の設定
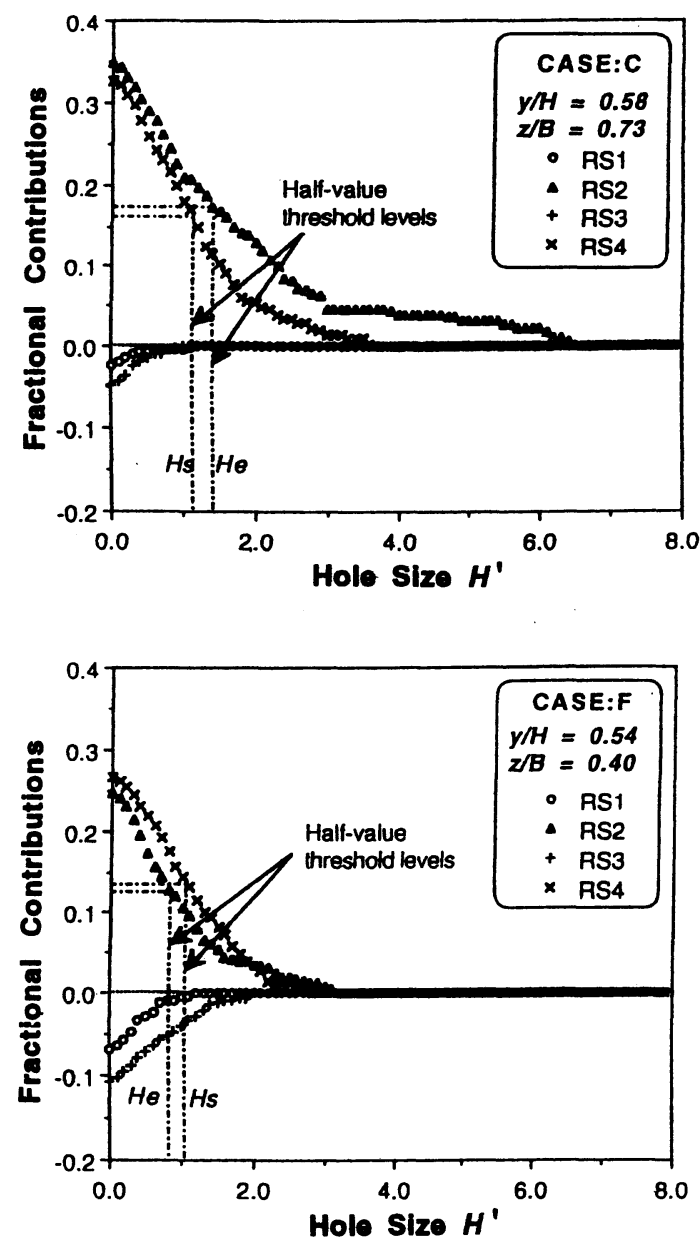

図-11 レイノルズ応力の各象限への奇与率

ここでは組織渦に関連しているとみなしうるレイノ ルズ応力が正の領域, すなわち第二象限と第四象限 のみを解析対象として，その際にしきい値の条件を 満たせば判別関数 $I=1$, 条件を満たさなければ $I=0$ と なるようにした，図-12は $\left|\widehat{u_{i}}\right|=\left|\mu_{i}\right| / u_{i}^{\prime}$ のように各点 での乱れ強度で規格化して表示したものである。こ

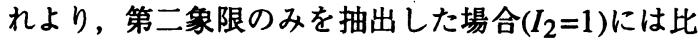
較的低速で低水路側へ，第四象限のみを抽出した場 合 $\left(I_{4}=1\right)$ には比較的高速で高水敷側へ移動する特性 が全般的に見られる。これらは前者が低速流体(組織 渦)に対応し，後者がそれを補う高速流体(補完流)に 対応するものと考えられる。このように特定条件下 での相関の移動方向・距離・大きさは高水敷と低水 路との相互作用を知る上での手がかりになるものと 考えられる。 

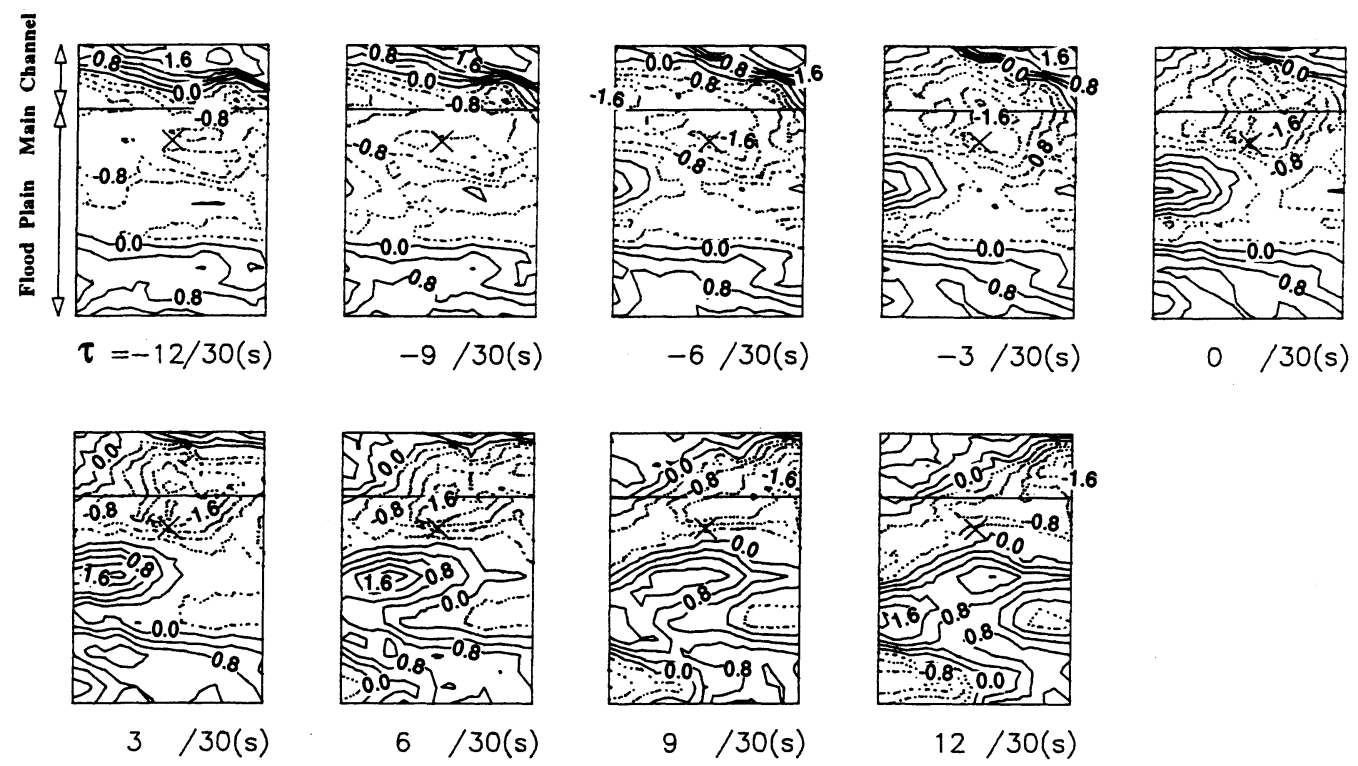

$12 / 30(s)$

(a) $<u>\left(\mathrm{I}_{2}=1\right.$, CASE:C, $\left.y / H=0.85\right)$
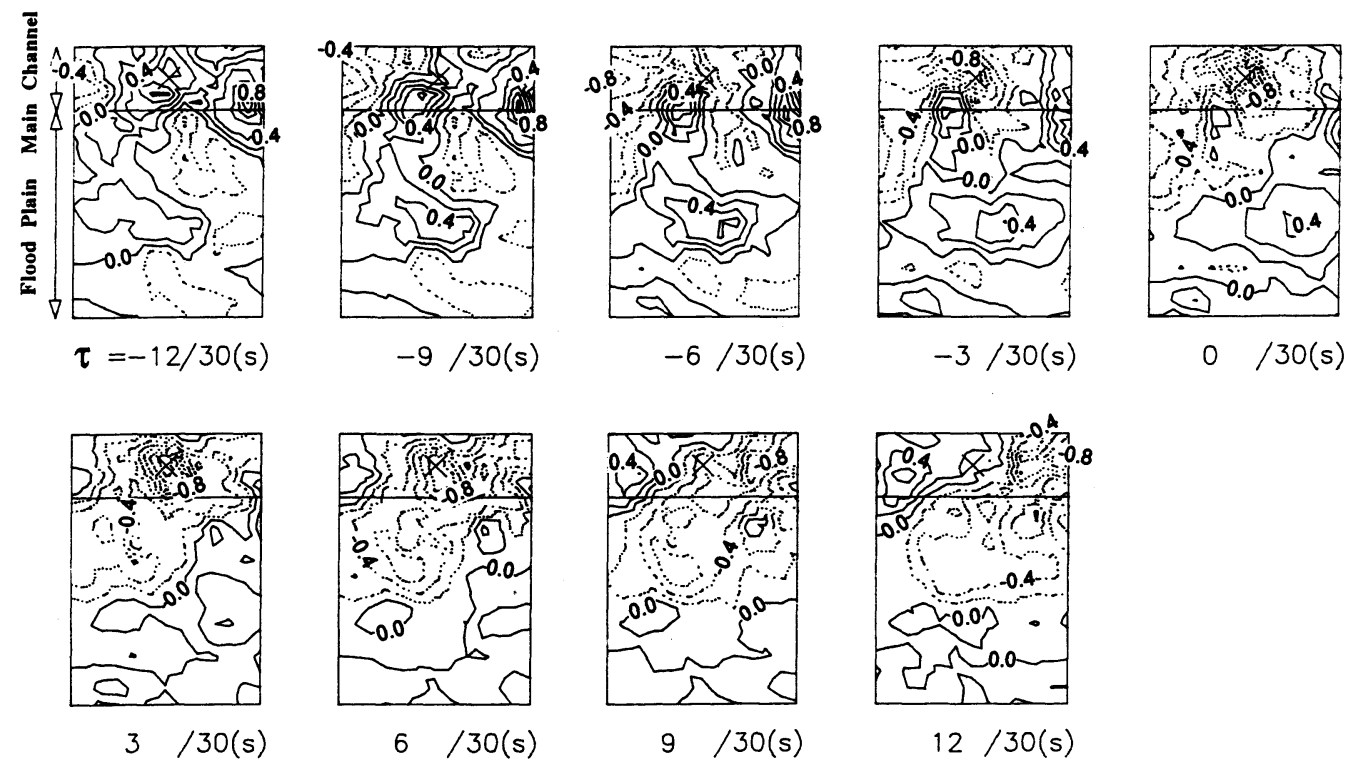

$12 / 30(s)$

(b) $<w>\left(I_{4}=1\right.$, CASE:C, $\left.y / H=0.85\right)$

図-12 条件付き時空間相関係数

\section{4. 結論}

本研究は，2次流に代表される組織渦による複断面 開水路流れの3 次元乱流構造について, 主に低水路と 高水敷間での相互作用に焦点を絞り，PTV法を用い て実験的に解明したものである. 直径 $100 \mu \mathrm{m}$, 比重 1.02のトレーサを水中に一様に混入し，LLSを照射し てCCDカメラで撮影して光ディスクに画像を記録し た.このPTV法を用いることによってLLS平面内の多 点同時ベクトルが得られ, 時空間相関解析や条件付
きサンプリング手法によって複断面開水路内の時空 間的な現象の解明を行った。 以下に本研究で得られ た知見を示す。

（1）PTV法とFLDAによる計測を比較することに よって, PTV法の精度の検証を行った．これより境 界部や画像解析範囲の端部で若干誤差が大きくなる 傾向が見られたが, 全体的に誤差は5\%程度であり PTV法による計測は比較的良い精度を持つことがわ かった. 
（2）無条件時空間相関解析を行うことによって, 平面的な場における相関の移流過程が示された. 特 に，水面付近と高水敷高さ付近では移流される方向 が異なり, 複断面流れにおける流体の移動・混合現 象と関わりがある.

（3）偏平率は境界部で特徴的な変化を示し, 組織 渦の変形過程は低水路と高水敷の相互作用と密接な 関係がある。

（4）条件付きサンプリング手法の1つである四象限 区分法を用いた。これより境界部をはさんで第二象 限もしくは第四象限が卓越しており，低速流体が高 水敷側から低水路側へ，それを補う高速流体が低水 路側から高水敷側へ移流していることが原因と考え られる。

（5）条件付き時空間相関解析を行うことによって 第二象限と第四象限のみを抽出し，移流過程を検証 した.これょり（4）の妥当性が示された。

謝辞：本研究を遂行するにあたり，新日本製鐵(株)技 術開発本部，伊佐隆善氏・津田宜久氏らより貴重な ご指導を受けたことを記し，謝意を表する。

\section{参考文畨}

1) 声田和男, 藤田正治, 劉柄義: 複断面直線河道におけ る浮遊砂の流送過程, 第32回水理講演会論文集, pp.461-466, 1988.

2) 福岡捷二, 藤田光一: 複断面河道の抵抗予測と河道計 画人の応用，土木学会論文集，第411号/II-12，pp.63$72,1989$.

3) 今本博健, 石垣泰㬍, 武藤裕則 : 複断面開水路流れに おける低水路流れと高水数上流れの混合機構に関す る実験的研究，水工学論文集，第36巻，pp.139-144, 1992.

4) 玉井信行, 河原能久: 複断面開水路流れの特性と抵抗 則に関する研究, 第25回水理講演会論文集, pp.113$118,1981$.

5）池田駿介，村山宜義，空閑健 : 椱断面開水路水平渦の
安定性とその3次元構造, 土木学会論文集, 第509号/ II-30, pp.131-142, 1995.

6) Tominaga, A. \& Nezu, I. : Turbulent structure in compound open channel flows, J. Hydraulic Eng., ASCE, 117(1), pp.21-41, 1991.

7) Naot, D., Nezu, I. \& Nakagawa, H. : Hydrodynamic behavior of compound rectangular open channels, $\mathrm{J}$. $\mathrm{Hy}$ draulic Eng., ASCE, 119(3), pp.390-408, 1993a.

8) Naot, D., Nezu, I. \& Nakagawa, H. : Calculation of compound open channel flow, J. Hydraulic Eng., ASCE, 119(12), pp.1418-1426, 1993b.

9) Utami, T. \& Ueno, T. : Experimental study on the coherent structure of turbulent open-channel flow using visualization and picture processing, J. Fluid Mech., 174, pp.399-440, 1987.

10）木下良作，宇民正，上野鉄男: 洪水時河川に現れる大 規模渦について, 第23回乱流シンポジウム講演論文 集, pp.329-334, 1991.

11）津田宜久，小林敏雄，佐賀徽雄：沉用PIVシステム (Current)の開発，第6回流れの計測大阪シンポジウム 論文集, pp.47-52, 1991.

12) Nezu, I., Nakagawa, H. \& Saeki, K. : Coherent structures in compound open-channel flows by making use of particletracking visualization technique, Proc. of Fundamentals and Advancements in Hydraulic Measurements and Experimentation, ASCE, pp.406-415, 1994.

13）今本博健，石垣泰輔: 複断面開水路流れの水理特性に ついて(4), 京都大学防災研究所年報, 第33号B-2, pp.559-569, 1990.

14) Nezu, I. \& Nakagawa, H. : Turbulence in Open-Channel Flows, IAHR-Monograph, Balkema, 1993.

15）今本博健，石坦泰輔，木下聖司: 複断面開水路流れの 水理特性について(2), 京都大学防災研究所年報, 第 27号B-2, pp.433-444, 1984.

\title{
SPACE-TIME CORRELATION ANALYSIS IN COMPOUND OPEN-CHANNEL FLOWS BY MAKING USE OF PARTICLE-TRACKING VELOCIMETRY
}

\author{
Iehisa NEZU, Takashi ABE, Takuya SHIMURA and Tadanobu NAKAYAMA
}

In compound open-channel flows, it is very important to clarify the interaction between main-channel and floodplain induced by coherent vortices, so-called secondary currents, etc. In this paper, a new quantitative visualization technique called the "Particle-Tracking Velocimetry (PTV)" was used to investigate space-time correlation structures of coherent vortices because instantaneous velocity components can be obtained at all grid points of laser-light-sheet (LLS) from continuous four images of one particle (four-field-images'method). At that time, a new-type two-component fiber-optic laser Doppler anemometer (FLDA) was used to verify the accuracy of PTV measurements. 